\title{
USE OF BAYESIAN NETWORKS AND AUGMENTED REALITY TO RELIABILITY TESTING OF COMPLEX TECHNICAL OBJECTS
}

\author{
WYKORZYSTANIE SIECI BAYESA \\ I RZECZYWISTOŚCI ROZSZERZONEJ DO BADAŃ \\ NIEZAWODNOŚCIOWYCH ZŁOŻONYCH OBIEKTÓW \\ TECHNICZNYCH
}

\author{
Tomasz Wójcicki \\ Institute For Sustainable Technologies \\ e-mail: tomasz.wojcicki@itee.radom.pl
}

\begin{abstract}
This paper presents a methodology developed to support the tests of reliability of complex technical objects. The presented methodology covers the use of modern information technologies in the form of algorithmic models and effective visualization techniques in the form of augmented reality. The possibility of using a probabilistic Bayesian network. The method of determining the probabilities for specific nodes, and the total probability distribution of graph structures are presented. The structure of the model and its basic functions are shown. The results of the verification work for connecting data processing methods and visualization techniques based on augmented reality are presented.
\end{abstract}

Keywords: Bayesian networks, probabilistic networks, augmented reality, reliability

Streszczenie: $W$ artykule przedstawiono opracowana metodyke wspomagania prowadzenia prac zwiazanych $z$ badaniami niezawodnościowymi złożonych obiektów technicznych. Zaprezentowana metodyka objęla wykorzystanie nowoczesnych technologii informatycznych $w$ postaci modeli algorytmicznych oraz efektywnych technik wizualizacji w postaci rzeczywistości rozszerzonej. Omówiono możliwość wykorzystania probabilistycznej sieci Bayesa. Przedstawiono metody wyznaczania prawdopodobieństwa zdarzeń dla określonych węzlów sieci oraz tacznego rozkładu prawdopodobieństwa dla struktur grafowych. Przedstawiono strukture opracowanego modelu i jego podstawowe funkcje. Zaprezentowano wyniki prac weryfikacyjnych połaczenia metod przetwarzania danych z wykorzystaniem technik wizualizacji bazujacych na rzeczywistości rozszerzonej.

Stowa kluczowe: sieć Bayesa, sieć probabilistyczna, rzeczywistość rozszerzona, niezawodność 
Use of bayesian networks and augmented reality to reliability testing of complex... Wykorzystanie sieci bayesa i rzeczywistości rozszerzonej do badań...

\section{Wstęp}

W obecnym, uprzemysłowionym świecie wzrasta zróżnicowanie oraz złożoność obiektów technicznych przeznaczonych do realizacji wielu funkcji. Postęp technologiczny przyczynia się do rozwoju złożonych konstrukcji mechanicznych i elektronicznych, dla których sprawne i bezbłędne prowadzenie procesów diagnostycznych stanowi narastający problem. Niezawodność obiektów technicznych jest ważnym czynnikiem determinującym ich nieprzerwane działanie oraz bezpieczeństwo osób je obsługujących. Nieprawidłowe funkcjonowanie obiektów technicznych może skutkować przestojami, a co za tym idzie znacznymi stratami finansowymi. Jest to również istotny czynnik warunkujący utrzymanie ciągłości produkcji. Skrócenie czasu związanego $\mathrm{z}$ prowadzeniem badań niezawodnościowymi oraz ich usprawnienie stanowi zatem istotne zagadnienie mające wpływ na możliwości badawcze ośrodków zajmujących się tymi zagadnieniami. Rozwój technologii, w tym technologii informatycznych wykorzystujących systemy wizualizacji umożliwia usprawnianie procesów, które jeszcze kilka lat temu realizowane były $\mathrm{z}$ wykorzystaniem technik organoleptycznych, ograniczonych niedoskonałościami percepcji człowieka. Badania niezawodnościowe mogą być prowadzone zarówno $\mathrm{w}$ warunkach laboratoryjnych jak też rzeczywistych warunkach eksploatacji i wymagać zaangażowania zasobów ludzkich oraz finansowych. Znaczącą rolę w tego typu przedsięwzięciach odgrywa również faza przygotowawcza. Opracowanie programu badań wymaga rozwiązania szeregu problemów jak: wyboru rodzaju gromadzonych danych, wyboru sposobu prowadzenia obserwacji, sposobu odwzorowania rzeczywistych warunków eksploatacji, sposobu gromadzenia i przetwarzania danych, sposobu łączenia danych pozyskanych $z$ heterogenicznych źródeł, itp. Zaprezentowane $\mathrm{w}$ artykule rozwiązanie stanowi narzędzie informatyczne usprawniające między innymi przygotowanie jak również prowadzenie procesów badawczych. Bardzo ważnym czynnikiem wpływającym na wiarygodność wyników są dane pozyskane $\mathrm{z}$ podobnych analiz i zestawienia statystyczne. Wiedza o formach i skutkach uszkodzeń oraz procesach regeneracji to jeden z elementów umożliwiających poznawanie mechanizmów prowadzących do stanu niezdatności.

\section{Charakterystyka złożonych obiektów technicznych}

Obiekt techniczny to system współpracujących elementów realizującym określone zadania. Układ taki może być analizowany holistycznie, jak również poprzez niezależne badanie jego poszczególnych elementów składowych. Niezależna analiza elementów tworzących obiekt techniczny nie musi dostarczać informacji o funkcjonalności całego obiektu technicznego informacje takie dostarcza dopiero wiedza o relacjach jakie zachodzą pomiędzy poszczególnymi elementami, stanowią one zatem istotny składnik badań niezawodnościowych szerokiej grupy maszyn i urządzeń. Złożony obiekt techniczny należy rozpatrywać jako uporządkowany zbiór elementów o określonej strukturze i zachodzących pomiędzy nimi relacjami. 
Cechą charakterystyczną obiektu technicznego jako całości jest to, że jego właściwości nie stanowią wyłącznie sumy właściwości elementów składowych oraz relacji zachodzących pomiędzy nimi ale także synergii, która może uwzględniać oddziaływanie otoczenia. Obecność oddziaływań w połączeniu z relacjami i cechami elementów obiektu technicznego determinuje całościowe właściwości systemu, które decydują o jego prawidłowym funkcjonowaniu. Złożone obiekty techniczne charakteryzują się zbiorem istotnych cech, które mają wpływ na procedury prowadzenia badań niezawodnościowych. Do cech tego rodzaju można zaliczyć: strukturę wewnętrzną (liczba oraz zróżnicowanie elementów), zakres funkcjonalności (zbiór możliwych do zrealizowania zadań), zakres oddziaływania $\mathrm{z}$ otoczeniem zewnętrznym (wpływ warunków zewnętrznych, jak np. temperatura, wilgotność, zapylenie, itp.), złożoność obsługi (zbiór czynności jakie powinny być wykonywane aby obiekt realizował przypisane $\mathrm{mu}$ funkcjonalności). Przedstawione cechy warunkują stosowanie określonych działań $\mathrm{w}$ procesach badawczych. Wiele metod badawczych związanych z analizami niezawodnościowymi nie uwzględnia czynnika ludzkiego co stanowi uproszczenie rozumienia uwarunkowań zewnętrznych, pomimo tego, że niezależne badania dowodzą, iż ponad $50 \%$ awarii i uszkodzeń obiektów technicznych powodowanych jest przez czynnik ludzki [1]. Tu w znaczącym zakresie może być użyteczne stosowanie nowoczesnych systemów technicznych, bazujących na technologiach informatycznych, zapewniających redukcję popełnianych przez operatorów maszyn i urządzeń błędów, których następstwem jest stan niezdatności. Ocena niezawodności złożonego obiektu technicznego jest oceną kompleksową, w skład której wchodzą oceny cząstkowe dla poszczególnych cech charakteryzujących analizowany system. Niezawodność dotyczyć może także złożonego obiektu technicznego eksploatowanego w wybranych warunkach zewnętrznych, a w przypadku obiektów o zmiennej strukturze dla ich wybranych układów, przewidzianych do realizacji określonych zbiorów zadaniowych. W niektórych złożonych obiektach technicznych stwierdzona niezgodność wartości cech $\mathrm{z}$ wymaganiami nie zawsze decyduje o jego niezdatności, może wówczas występować stan nazywany niezdatnością pośrednią, a obiekt taki charakteryzuje się tzw. nadmiarową strukturą niezawodnościową [2]. Nadmiarowość może dotyczyć: elementów wchodzących w skład złożonego obiektu technicznego (tzw. układów rezerwowych), funkcjonalności, wymagań czasowych, wymagań informacyjnych (redundancji danych), zbiorów parametrów wejściowych oraz wyjściowych, wymagań wytrzymałościowych (związanych $\mathrm{z}$ konstrukcjami mechanicznymi). Poszczególne rodzaje nadmiarowości mogą występować pojedynczo lub łącznie. Tego typu rozwiązania można spotkać przeważnie tam, gdzie znaczącą rolę odgrywa bezpieczeństwo (np. w lotnictwie). Do analiz niezawodnościowych złożonych obiektów technicznych można stosować dekompozycje prowadzone wg przyjętych założeń. Dekompozycje takie mogą być jedno lub wielokrotne. Dekompozycje wielokrotne wykorzystywane są gdy zachodzi potrzeba analizy struktur poszczególnych elementów tworzących obiekt techniczny. W takim przypadku każdy $\mathrm{z}$ elementów wchodzących $\mathrm{w}$ skład głównego obiektu technicznego może być traktowany jako niezależny obiekt techniczny, przy czym ilość tego typu zagłębień jest teoretycznie nieograniczona. Istotną rolę $\mathrm{w}$ analizach niezawodnościowych złożonych obiektów technicznych odgrywa także ważność poszczególnych elementów w strukturze systemu 
Use of bayesian networks and augmented reality to reliability testing of complex... Wykorzystanie sieci bayesa i rzeczywistości rozszerzonej do badań...

poddawanego badaniom, tzn. ocena, który z elementów w jak największym stopniu ma wpływ na niezawodność maszyny lub urządzenia. Aby określić ten parametr stosowane są różne miary jak np.: Birnbauma [3], Barlowa-Proschana [4], Natviga [5], Lamberta [6]. Opracowany model usprawnienia badań niezawodnościowych złożonych obiektów technicznych zakłada wykorzystanie nowoczesnych systemów informatycznych do wspomagania działań związanych $\mathrm{z}$ prowadzeniem prac diagnostycznych. Dwa główne składniki opracowanego modelu to rozwiązanie techniczne w postaci systemu rzeczywistości rozszerzonej oraz rozwiązanie obliczeniowe w postaci sieci Bayesa.

\section{Model wizyjnego wspomagania badań niezawodnościowych}

Wizyjne wspomaganie badań niezawodnościowych zakłada wykorzystanie systemu rzeczywistości rozszerzonej do wspomagania personelu technicznego podczas badań obiektów technicznych o złożonych konstrukcjach w celu skrócenia czasu przygotowania do badań i redukcji popełnianych błędów. Główne elementy struktury opracowanego systemu to: autorskie oprogramowanie do przetwarzania i analizy obrazów, serwer, urządzenie projekcyjne, kamera cyfrowa rejestrująca obraz analogiczny do widzianego przez operatora systemu, komputer użytkownika, manipulator. W czasie pracy obraz wyświetlany przez urządzenie projekcyjne wzbogacany jest obiektami wirtualnymi generowanymi przez opracowane oprogramowanie komputerowe na podstawie przygotowanych interaktywnych instrukcji cyfrowych $\mathrm{w}$ celu wskazania operatorowi lokalizacji i czynności koniecznych do przeprowadzenia badań niezawodnościowych. Od strony oprogramowania informatycznego system funkcjonuje według technologii klientserwer, która zapewnia możliwość zdalnego pobierania danych (rys. 1).

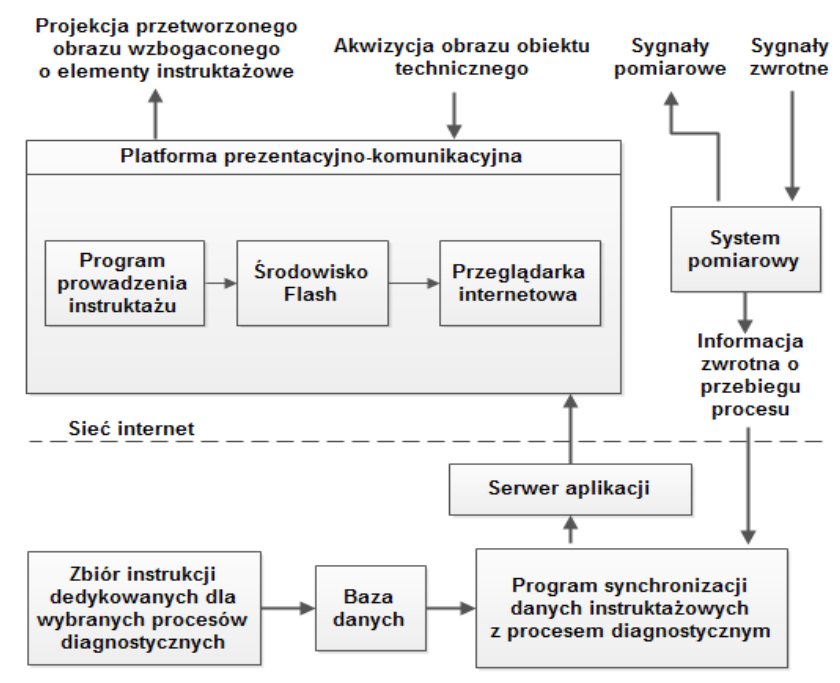

Rys. 1 Struktura oprogramowania systemu rzeczywistości rozszerzonej przeznaczonego do wspomagania badań niezawodnościowych złożonych obiektów technicznych 
Prowadzenie procesów badań niezawodnościowych $\mathrm{z}$ wykorzystaniem opracowanego systemu realizowane jest poprzez wizyjną prezentację operatorowi: lokalizacji elementów składowych analizowanego obiektu technicznego, przewidzianych czynności, podpowiedzi opisowych w formie tekstowej, wartości pomiarowych, lokalizacji punktów pomiarowych, modeli 3D elementów składowych obiektu technicznego. Proces przebiega z wykorzystaniem elementów fizycznych oraz logicznych, które mają wpływ na decyzje podejmowane przez operatora. (rys. 2).

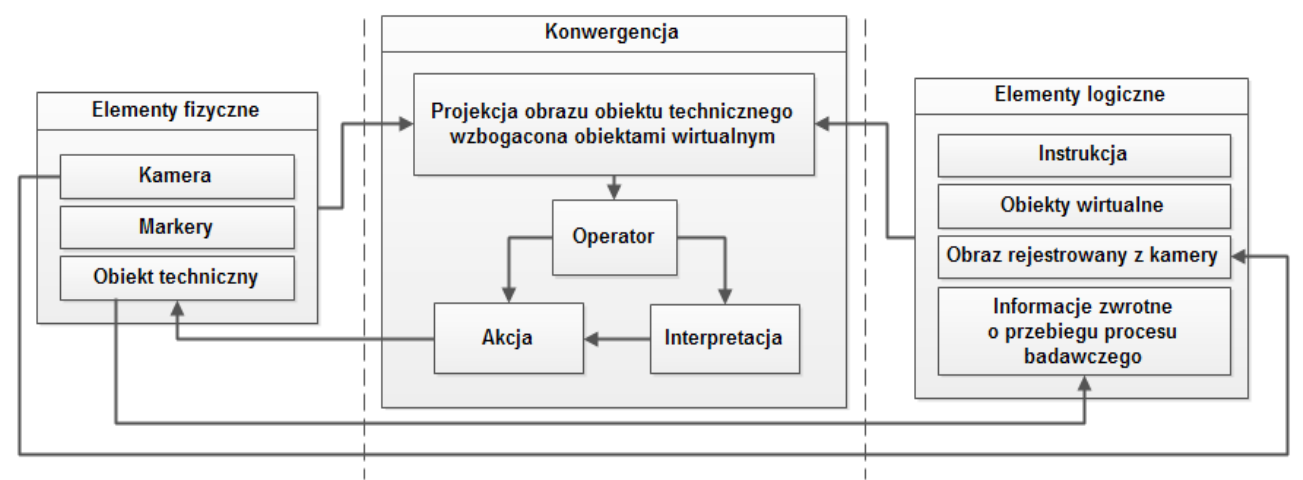

Rys. 2 Schemat zależności pomiędzy elementami fizycznymi i logicznymi podczas procesu badań niezawodnościowych z wykorzystaniem systemu rzeczywistości rozszerzonej

Operator na podstawie projekcji obrazu obiektu technicznego wzbogaconej treścią interaktywnych instrukcji $\mathrm{z}$ naniesionymi elementami wirtualnymi dokonuje interpretacji dotyczącej stanu obiektu, po czym podejmuje decyzję co do dalszych działań opisanych z wykorzystaniem interaktywnej instrukcji (rys. 3).
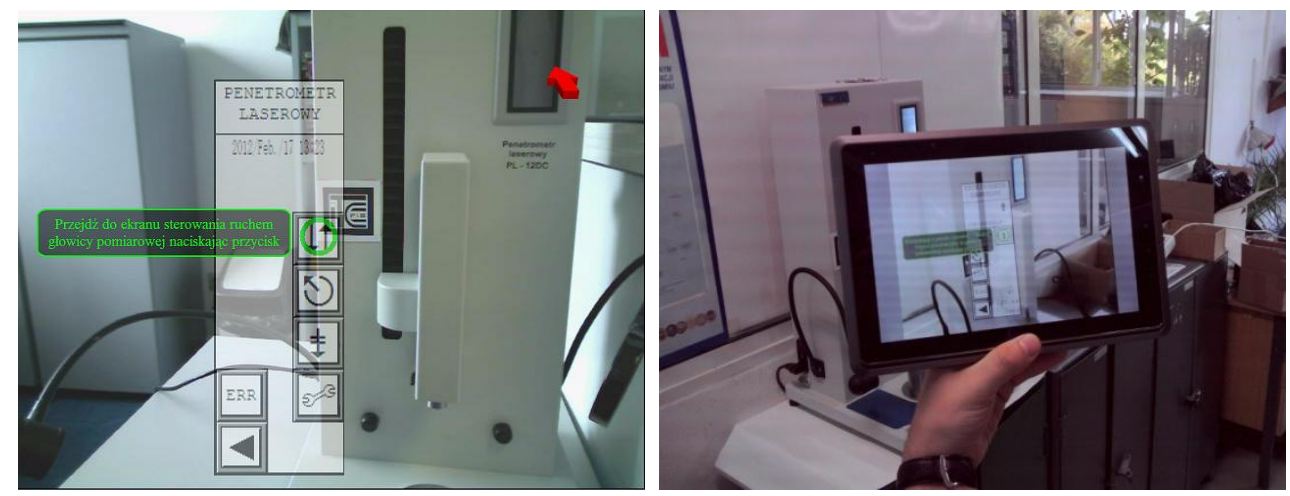

Rys. 3 Przyklad wykorzystania opracowanego systemu rzeczywistości rozszerzonej do badań niezawodnościowych penetrometru laserowego PL-12DC-4 
Use of bayesian networks and augmented reality to reliability testing of complex... Wykorzystanie sieci bayesa i rzeczywistości rozszerzonej do badań...

Działania operatora poprzez informacje zwrotne o przebiegu procesu sygnalizowane są wizualnie, dzięki czemu następuje potwierdzenie czy zostały one wykonane poprawnie. $\mathrm{W}$ przypadku prac, które nie są sprzężone $\mathrm{z}$ elementami generującymi informacje zwrotne, poprawność wykonanych czynności rozpoznawana jest przez operatora na podstawie porównania stanu fizycznego obiektu z prezentacją wizualną składającą się z elementów wirtualnych w postaci opisu tekstowego lub graficznego.

\section{Model wspomagania badań niezawodnościowych z wykorzystaniem sieci Bayesa}

W zaproponowanym rozwiązaniu modelowym metoda identyfikacji elementów złożonych obiektów technicznych w największym stopniu podatnych awarie oparta jest na usystematyzowanej wiedzy dotyczącej podobnych zdarzeń oraz acyklicznych grafach skierowanych charakteryzujących specyfikę obiektów technicznych. Umożliwia to identyfikację elementów składowych obiektów technicznych do badań niezawodnościowych na podstawie wiedzy charakteryzującej inne obiekty techniczne mogące różnić się niektórymi cechami konstrukcyjnymi. Model ogólny reprezentuje system informatyczny, którego zadaniem jest transformacja wielkości wejściowych $X_{M}$ w wielkości wyjściowe $Y_{M}$ z wykorzystaniem operatora $F_{M}$.

Model formalny systemu jest następujący:

$$
F_{M}: X_{M} \rightarrow Y_{M}
$$

gdzie:

$$
\begin{aligned}
& F_{M}-\text { operator działania modelu; } \\
& X_{M}-\text { przestrzeń wielkości wejściowych; } \\
& Y_{M}-\text { przestrzeń wielkości wyjściowych. }
\end{aligned}
$$

Przestrzeń wielkości wejściowych $X_{M}$ stanowi zbiór funkcjonalności wybranych obiektów technicznego, zbiór cech charakteryzujących elementy składowe obiektów technicznych, zbiór wiedzy o przebytych awariach:

$$
X_{M}=\left\{X^{p}, X^{e}, X^{a}\right\}
$$

gdzie:

$X_{M}-$ przestrzeń wielkości wejściowych;

$X^{p}=\left\{x_{1}^{p}, x_{2}^{p}, \ldots, x_{i}^{p}\right\}$ - zbiór funkcjonalności obiektów technicznych;

$X^{e}=\left\{x_{1}^{e}, x_{2}^{e}, \ldots, x_{j}^{e}\right\} \quad$ - zbiór cech charakteryzujących elementy składowe obiektów technicznych;

$X^{a}=\left\{x_{1}^{a}, x_{2}^{a}, \ldots, x_{k}^{a}\right\} \quad$ - zbiór wiedzy o przebytych awariach. 
Przestrzeń wielkości wyjściowych $Y_{M}$ stanowi zbiór informacji o elementach obiektów technicznych podatnych na awarie:

$$
Y_{M}=Y^{g}
$$

gdzie:

$$
\begin{array}{ll}
Y_{M}-\text { przestrzeń wielkości wyjściowych; } \\
Y^{g}=\left\{y_{1}^{g}, y_{2}^{g}, \ldots, y_{m}^{g}\right\}- & \text { zbiór informacji o elementach obiektów } \\
& \text { technicznych podatnych na awarie. }
\end{array}
$$

Proces wnioskowania odbywa się przy wykorzystaniu probabilistycznej sieci Bayesa, która jest acyklicznym grafem skierowanym, zbudowanym z węzłów oraz łączących je krawędzi. Węzły to zmienne reprezentujące określone zdarzenia, natomiast krawędzie to relacje zachodzące pomiędzy zdarzeniami z przypisanymi do nich określonymi stopniami prawdopodobieństwa. Sieci Bayesa odzwierciedlają strukturę przyczynową-skutkową wybranego obszaru problemowego. Istotną cechą sieci Bayesa jest możliwość wyznaczenia rozkładów prawdopodobieństwa określonych zmiennych (zdarzeń) na podstawie stanów pozostałych zmiennych. Zakładając, że A i B reprezentują zdarzenia i prawdopodobieństwo wystąpienia zdarzenia B wynosi $P(B)>0$, wówczas warunkowe prawdopodobieństwo wystąpienia zdarzenia A wyznaczane jest ze wzoru:

$$
P(A \mid B)=\frac{P(B \mid A) P(A)}{P(B)}
$$

Przy założeniu, że A może przyjmować n stanów $\left\{a_{1}, a_{2}, \ldots, a_{n}\right\}$, wówczas dla i-tego stanu prawdopodobieństwo a priori zdarzenia $\mathrm{B}$ wyznaczane jest według równania:

$$
P(B)=\sum_{i=1}^{n} P\left(B \mid A=a_{i}\right) P\left(A=a_{i}\right)
$$

Łączny rozkład prawdopodobieństwa $\mathrm{w}$ sieci Bayesa złożonej $\mathrm{z}$ k węzłów wyznaczany jest na podstawie prawdopodobieństw warunkowych poszczególnych zdarzeń dla określonych wartości ich poprzedników:

$$
P\left(A_{1}, \ldots, A_{m}\right)=\prod_{k=1}^{m} P\left(A_{k} \mid \operatorname{parent}\left(A_{k}\right)\right)
$$

$\operatorname{parent}\left(A_{k}\right)$ - zbiór węzłów poprzedzających bezpośrednio węzeł $A_{k}$.

Na podstawie wiedzy o łącznym rozkładzie prawdopodobieństwa możliwe jest prowadzenie wnioskowania dotyczącego wartości prawdopodobieństw zdarzeń uwzględnionych $w$ strukturze sieci. Wnioskowanie może być przyczynowe (dotyczące zdarzeń odwzorowujących przyczyny) oraz skutkowe (dotyczące zdarzeń reprezentujących skutki). 
Use of bayesian networks and augmented reality to reliability testing of complex... Wykorzystanie sieci bayesa i rzeczywistości rozszerzonej do badań...

Wybór wnioskowania uzależniony jest od rodzaju problemu, który odwzorowuje struktura sieci. W przypadku złożonych problemów dotyczących setek tysięcy zdarzeń struktura sieci może być na tyle złożona, że ze względów efektywnościowych stosuje się algorytmy, których jednym $\mathrm{z}$ celów jest zredukowanie czasu prowadzenia analizy. Dwa najpopularniejsze algorytmy to: metoda logicznego próbkowania [7] oraz metoda ważonego próbkowania [8]. Dla przyjętych założeń modelowych prawdopodobieństwo warunkowe opisujące węzły reprezentujące elementy składowe złożonego obiektu technicznego przedstawia równanie:

$$
P\left(y_{f}^{g} \mid x_{1}^{p} \ldots x_{i}^{p}, x_{1}^{e} \ldots x_{j}^{e}, x_{1}^{a} \ldots x_{k}^{a}\right)=\prod_{h=1}^{i} P\left(x_{h}^{p}\right) \prod_{d=1}^{j} P\left(x_{d}^{e}\right) \prod_{q=1}^{k} P\left(x_{q}^{a}\right), f=1 \ldots m
$$

Z wykorzystaniem przedstawionego równania możliwe jest prowadzenie procesów oceny prawdopodobieństwa wystąpienia awarii w poszczególnych elementach struktury maszyny lub urządzenia na podstawie znanych danych o innych obiektach technicznych mogących różnić się niektórymi cechami konstrukcyjnymi.

\section{Weryfikacja opracowanego rozwiązania}

Celem weryfikacji opracowanego rozwiązania modelowego było sprawdzenie możliwości wspomagania prowadzenia procesu badań niezawodnościowych, od strony wizyjnej, poprzez wykorzystanie systemu rzeczywistości rozszerzonej jak również od strony obliczeniowej poprzez prognozowanie wyboru elementów w jak największym stopniu podanych na awarie. Do analizy wytypowano obiekt techniczny w postaci opracowanego w Instytucie Technologii Eksploatacji - PIB w Radomiu penetrometru laserowego PL-12DC-4, który jest urządzeniem wykorzystującym technikę laserową do pomiaru głębokości penetracji badanych próbek, którymi mogą być produkty petrochemiczne (np. smary, asfalty, parafiny), produkty spożywcze (np. masła, margaryny), wyroby kosmetyczne (np. kremy), a także zaprawy murarskie oraz plastyczne materiały wybuchowe.

$\mathrm{W}$ pierwszym etapie prac weryfikacyjnych przeprowadzono proces dekompozycji struktury penetrometru laserowego PL-12DC-4 oraz dwóch analogicznych konstrukcji o zbliżonych funkcjonalnościach (PL-12DC-3, PL-12DC-2) dla których znane były przyczyny występowania awarii $\mathrm{w}$ celu identyfikacji elementów składowych. W wyniku przeprowadzonego wnioskowania przy wykorzystaniu opracowanego modelu obliczeniowego wytypowano 3 elementy dla których prawdopodobieństwo wystąpienia awarii po roku użytkowania urządzenia było największe, co potwierdziło wykonalność tego procesu. Były to:

- zespół napędu głowicy pomiarowej - $P\left(y^{g}\right)=22 \%$,

- wentylator $-P\left(y^{g}\right)=17 \%$,

- zespół sterowania $P\left(y^{g}\right)=6 \%$,

W kolejnym etapie prac weryfikacyjnych sprawdzono możliwość wizyjnego wspomagania prowadzenia badań niezawodnościowych z wykorzystaniem systemu 
rzeczywistości rozszerzonej. Dla celów badawczych wytypowano 6 osób, które miały przeprowadzić zaplanowane zdania $\mathrm{z}$ wykorzystaniem penetrometru laserowego składające się z 5, 10, 15, 25 i 40 czynności. Grupę podzielono na dwie w skład których wchodziły po 3 osoby. Pierwsza grupa została przeszkolona $\mathrm{w}$ posługiwaniu się penetrometrem oraz zaznajomiona $\mathrm{z}$ przebiegiem zaplanowanych badań, druga grupa wykonywała polecenia wyświetlane przez system rzeczywistości rozszerzonej wraz z podpowiedziami w postaci elementów wirtualnych nałożonych na obraz rzeczywistego obiektu technicznego. Celem było określenie wpływu wykorzystania opracowanego rozwiązania na czas prowadzonych czynności przez osoby, które nie zostały poddane wcześniejszemu przeszkoleniu. Wyniki badań przedstawiono na rys. 4.

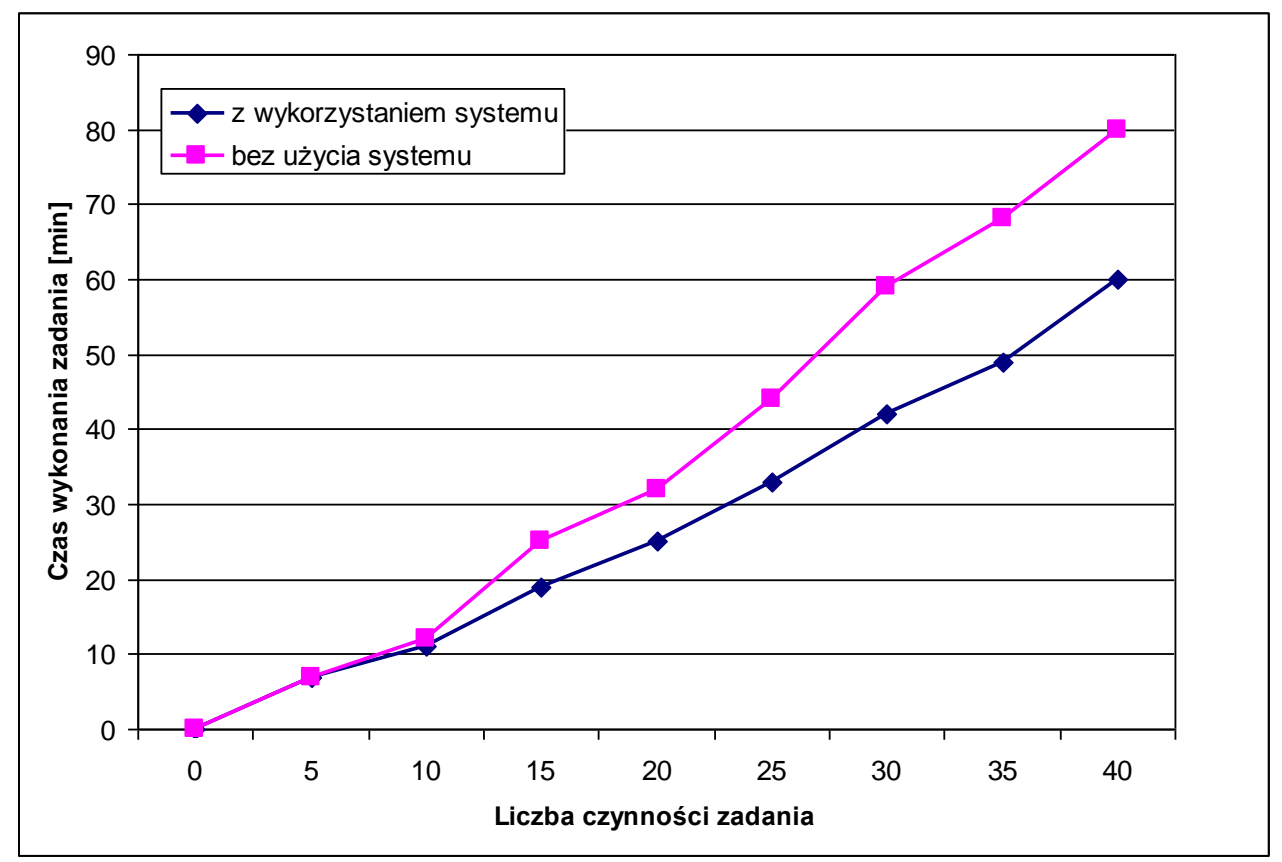

Rys. 4 Wpływ liczby czynności na czas wykonania zaplanowanego zadania zwiazanego z badaniami niezawodności penetrometru laserowego przez osoby korzystajace wyłącznie z klasycznej dokumentacji technicznej (drukowanej) oraz opracowanego systemu rzeczywistości rozszerzonej

Stwierdzono także wpływ wykorzystania opracowanego rozwiązania na ilość błędów popełnianych podczas badań niezawodnościowych. W przypadku personelu nie korzystającego $\mathrm{z}$ opracowanego systemu stwierdzono, że ilość popełnianych błędów wzrasta znacznie szybciej niż ilość błędów popełnianych przez personel korzystający $\mathrm{z}$ systemu. Ma to szczególne znaczenie kiedy czynności wykonywane są w znacznych odstępach czasowych. 
Use of bayesian networks and augmented reality to reliability testing of complex... Wykorzystanie sieci bayesa i rzeczywistości rozszerzonej do badań...

\section{Podsumowanie}

Wykorzystanie nowoczesnych rozwiązań informatycznych w tym systemów rzeczywistości rozszerzonej może wnosić wiele korzyści poprawiających efektywność procesów badawczych. Rozwiązania tego typu charakteryzują się dużą dynamiką rozwoju oraz znajdują zastosowanie w coraz szerszym obszarze aplikacyjnym, w tym także w zastosowaniach badawczych. Tworzą one również nową jakość wynikającą $\mathrm{z}$ immersyjności, pobudzającej użytkownika do interaktywności i skupiania uwagi na przekazywanych treściach. Szczególnie korzystny wpływ wykorzystania tego typu rozwiązań można zauważyć w przypadku badań wykonywanych na maszynach i urządzeniach o złożonych konstrukcjach, gdzie bez długotrwałego, wstępnego zapoznania się z dokumentacją techniczną, identyfikacja poszczególnych elementów składowych możne stanowić znaczące utrudnienie. Kolejnym istotnym elementem mającym wpływ na efektywność prowadzonych procesów badawczych ma wykorzystanie wiedzy apriorycznej. Poprzez zastosowanie informacji pochodzących $\mathrm{z}$ prowadzonych niezależnie innych rodzajów badań, które mogą być realizowane różnymi technikami jak: analiza drgań i zjawisk wibroakustycznych, zjawisk cieplnych, zjawisk elektromagnetycznych, badań ultradźwiękowych, badań zmian wizualnych, możliwe jest prowadzenie procesów inferencji dotyczących pozyskania informacji o elementach podatnych na uszkodzenia i możliwych przyczynach awarii. Analiza uzyskanych wyników wskazuje na możliwości wykorzystania opracowanego rozwiązania w praktyce. Zalety metody uwydatniają się tym bardziej im bardziej złożona jest struktura obiektu technicznego oraz im bardziej skomplikowany jest proces wymagający przeprowadzenia określonego zbioru czynności. Na podstawie badań empirycznych stwierdzono, że zysk czasowy związany z przeprowadzeniem określonych zabiegów eksploatacyjnych jest tym większy im większa jest zaplanowana liczba niezbędnych do wykonania czynności. Znaczącą zaletą opracowanej metody jest również jej uniwersalność, polegająca na możliwości stosowania jej dla szerokiego zakresu obiektów technicznych.

\section{Literatura}

[1] Laskowski D.: Prognozowanie niezawodności złożonych obiektów technicznych, Biuletyn WAT, nr 55/2006, s. 275-291.

[2] Młyńczak M.: Metodyka badań eksploatacyjnych obiektów mechanicznych, Oficyna Wydawnicza Politechniki Wrocławskiej, Wrocław 2012.

[3] Legutko S.: Podstawy eksploatacji maszyn i urządzeń, Wydawnictwa Szkolne i Pedagogiczne, Warszawa 2004.

[4] Pazur A.: Mathematical model of the reliability of the communication computer in the integrated communication systems of military helicopters, Journal of KOBiN, nr 4/2010, s. 135-152. 
[5] Matuszak Z.: Components validity evaluation in a complex technical structure, Zeszyty Naukowe Akademia Morska w Szczecinie, nr 32/2012, s. $115-122$.

[6] Młynarski S.: Problemy określania niezawodności w eksploatacji maszyn i pojazdów, Problemy Eksploatacji, nr 2/2003, s. 165-174.

[7] Gregory P.: Bayesian Logical Data Analysis for the Physical Sciences, Cambridge University Press, Cambridge 2005.

[8] Jensen F., Nielsen T.: Bayesian Network and Decision Graphs, Springer, USA 2009.

Dr inż. Tomasz Wójcicki - adiunkt w Zaktadzie Technologii Informatycznych Instytutu Technologii Eksploatacji - PIB $w$ Radomiu. Zawodowo zajmuje sie zagadnieniami z obszaru budowy rozwiazań informatycznych $z$ zakresu sztucznej inteligencji, systemów sterowania, przetwarzania $i$ analizy obrazów cyfrowych, eksploracja danych, modelowania procesów produkcji. 
Use of bayesian networks and augmented reality to reliability testing of complex... Wykorzystanie sieci bayesa i rzeczywistości rozszerzonej do badań... 